\title{
Toxicity of Citrate-Capped Silver Nanoparticles in Common Carp (Cyprinus carpio)
}

\author{
Byoungcheun Lee, ${ }^{1}$ Cuong Ngoc Duong, ${ }^{1}$ Jaegu Cho, ${ }^{1}$ Jaewoo Lee, ${ }^{1}$ Kyungtae Kim, ${ }^{1}$ \\ Youngrok Seo, ${ }^{2}$ Pilje Kim, ${ }^{1}$ Kyunghee Choi, ${ }^{1}$ and Junheon Yoon ${ }^{1}$ \\ ${ }^{1}$ Risk Assessment Division, National Institute of Environmental Research (NIER), Nanji-ro 184, Seo-gu,
Incheon 404-708, Republic of Korea
${ }^{2}$ Department of Life Science, College of Life Science and Biotechnology, Dongguk University, Jung-gu, Seoul 100-715, Republic of Korea
}

Correspondence should be addressed to Junheon Yoon, soiljh@korea.kr

Received 8 May 2012; Revised 24 July 2012; Accepted 24 July 2012

Academic Editor: Kazim Husain

Copyright (C) 2012 Byoungcheun Lee et al. This is an open access article distributed under the Creative Commons Attribution License, which permits unrestricted use, distribution, and reproduction in any medium, provided the original work is properly cited.

Juvenile common carp (Cyprinus carpio) were used as a model to investigate acute toxicity and oxidative stress caused by silver nanoparticles (Ag-NPs). The fish were exposed to different concentrations of Ag-NPs for $48 \mathrm{~h}$ and $96 \mathrm{~h}$. After exposure, antioxidant enzyme levels were measured, including glutathione-S-transferase (GST), superoxidase dismutase, and catalase (CAT). Other biochemical parameters and histological abnormalities in different tissues (i.e., the liver, gills, and brain) were also examined. The results showed that Ag-NPs agglomerated in freshwater used during the exposure experiments, with particle size remaining $<100 \mathrm{~nm}$. Ag-NPs had no lethal effect on fish after 4 days of exposure. Biochemical analysis showed that enzymatic activities in the brain of the fish exposed to $200 \mu \mathrm{g} / \mathrm{L}$ of Ag-NPs were significantly reduced. Varied antioxidant enzyme activity was recorded in the liver and gills. Varied antioxidant enzyme activity was recorded for CAT in the liver and GST in the gills of the fish. However, the recovery rate of fish exposed to $200 \mu \mathrm{g} / \mathrm{L}$ of Ag-NPs was slower than when lower particle concentrations were used. Other biochemical indices showed no significant difference, except for $\mathrm{NH}_{3}$ and blood urea nitrogen concentrations in fish exposed to $50 \mu \mathrm{g} / \mathrm{L}$ of Ag-NPs. This study provides new evidence about the effects of nanoparticles on aquatic organisms.

\section{Introduction}

Nanomaterials occur in nature via various geobiophysicochemical processes, such as volcanic eruptions, bacterial metabolism, and other erosion and reduction mechanisms. In recent decades, nanoparticles have been increasingly manufactured and used in daily consumer products, such as textiles, paints, pharmaceuticals, and cosmetic products, as well as in pollution treatment and remediation processes [1, $2]$. However, it is widely known that nanoparticles may cause potential adverse effects in organisms, including human and mammals [3-7]. Consequently, the adverse effects of incompletely retrieved nanoparticles pose an increasing threat to the public [7-9]. Therefore, it is important to develop an understanding of the effects and active mechanisms of nanoparticles.

Silver $(\mathrm{Ag})$ is among the most used metals in human life and is well known for its antimicrobial effect. During the recent rapid development of nanotechnology, silver nanoparticles (Ag-NPs) have been used for various types of consumer products, such as cosmetics, heath care products, and textiles. Consequently, information about the toxicity and carcinogenic effects of Ag is available, with it being considered nontoxic and noncarcinogenic when used in appropriate amounts [10]. However, at relatively high concentrations, Ag-NPs cause cellular toxicity and other adverse impacts, such as the inhibition of mitochondrial function in rat liver cells, mouse germline stem cells, and human fibroblasts [1113]. Furthermore, an increasing number of recent reports have provided evidence of the cytotoxicity of Ag-NPs at doses of low exposure $[14,15]$. Ag-NPs also have an adverse impact on aquatic organisms, such as zebrafish and medaka fish, and cause oxidative stress, cellular apoptosis, chromosomal aberrations [16], and other developmental toxicity effects during early life stages and adulthood [17]. Nanoparticles combined with other substances may also threaten organisms 
TABLE 1: Measurements of the common carp used in the experiments.

\begin{tabular}{|c|c|c|c|c|c|}
\hline Ag-NP concentration & Fish length $(\mathrm{cm})$ & Fish weight $(\mathrm{g})$ & Liver (g) & Gill (g) & Brain (g) \\
\hline Control & 12.1 & 25.1 & 0.694 & 0.653 & 0.232 \\
\hline $25 \mu \mathrm{g} / \mathrm{L}$ & 12.7 & 28.2 & 0.698 & 0.736 & 0.298 \\
\hline $50 \mu \mathrm{g} / \mathrm{L}$ & 12.1 & 24.4 & 0.631 & 0.573 & 0.285 \\
\hline $100 \mu \mathrm{g} / \mathrm{L}$ & 11.5 & 21.5 & 0.624 & 0.507 & 0.269 \\
\hline $200 \mu \mathrm{g} / \mathrm{L}$ & 12.6 & 25.9 & 0.790 & 0.704 & 0.306 \\
\hline Minimum & 10.9 & 18.6 & 0.386 & 0.492 & 0.219 \\
\hline Maximum & 13.5 & 33.8 & 0.977 & 0.840 & 0.350 \\
\hline Average & 12.2 & 25.0 & 0.687 & 0.635 & 0.278 \\
\hline
\end{tabular}

in other ways. This is because changes in the functional groups on the nanoparticle surface may facilitate substances to penetrate deep into the cells of the body, causing unexpected impacts on organisms. However, it is unclear whether the effects of coating materials increase the adverse effects of nanomaterials. In this study, we investigated the effects of Ag-NPs in the presence of citric acid as a capping material. Citric acid is an organic chemical commonly found in the natural environment and human body. Therefore, the interaction of citric acid with exposed materials is a common mechanism in the natural environment.

Common carp (Cyprinus carpio) is an abundant species in the freshwater environment. Due to their large size, carp have a better capacity for resistance to pollutants than other laboratory fish, such as zebrafish and Japanese medaka. Hence, carp are not usually used in experiments to examine the fatal effects of exposure to low doses of pollutants. However, because of the dominance of this species in the natural environment, carp is considered as one of the most suitable models to assess the non-fatal effects of pollutants by evaluating fluctuations in antioxidant enzyme levels or other changes in fish histology and physiology.

The objectives of this study were to investigate the adverse effects of Ag-NPs capped with citric acid (Ag-NPs) by measuring antioxidant enzymatic activities, including those of catalase (CAT), superoxide dismutase (SOD), and glutathione-S-transferase (GST). Target organs included the brain, liver, and gills of the common carp (C. carpio). In addition, other biochemical parameters in the blood and histological changes in the skin, liver, and gills of the fish were examined.

\section{Materials and Methods}

2.1. Chemicals and Reagents. In the current study, we developed on the work of our previous study [18]. For this reason, we used the same biological samples as those used in the previous study to present detailed data about the toxicity of nanoparticles.

All chemicals were purchased from Sigma-Aldrich and were of analytical grade or better. Citrate-capped Ag-NPs were purchased from ABCNanotech (Daejeon, Korea) in a suspension form. The average particle size stipulated by the manufacturer was $15 \mathrm{~nm}$. Particles were dispersed in deionized (DI) water as black colloids. The average $\mathrm{pH}$ of the original solution was 6.5 , with a particle content of $20 \%$ by weight. The dispersion of the particles was confirmed using a transmission electron microscope (TEM; JEOL, Japan) and the dynamic Light scattering method (DLS; ELS-8000, Otsuka, Japan). A stock solution of Ag-NPs was prepared at $10 \mathrm{mg} / \mathrm{L}$. Working solutions $(25,50,100$, and $200 \mu \mathrm{g} / \mathrm{L})$ were obtained by diluting the stock solution with respective amounts of DI water.

The concentration of elemental Ag was measured using an inductive coupled plasma mass spectrometer (ICP-MS, Perkin Elmer, USA). Mean concentrations were obtained by using the data to plot a standard curve with Ag standard solution (SCP Science, QC, Canada) and $5 \% \mathrm{HNO}_{3}$ solution (electronic grade, SCP science, QC, Canada). The ranges of the standard were $0.0,1.0,5.0,10.0,20.0,40.0,60.0,80.0$, and $100.0 \mu \mathrm{g} / \mathrm{L}$, and the $r^{2}$ value was 0.9997 .

2.2. Carp Breeding and Maintenance. Juvenile carp were obtained from the National Academy of Agricultural Science, Korea. As shown in Table 1, the body weight and length of the fish were $18.6 \sim 33.8 \mathrm{~g}$ and $10.9 \sim 13.5 \mathrm{~cm}$, respectively. The freshwater used to culture the fish was dechlorinated and continuously aerated. Water temperature was kept at $24 \pm 1^{\circ} \mathrm{C}$, hardness was maintained at $40 \sim 60 \mathrm{mg} \mathrm{CaCO} / \mathrm{L}$, $\mathrm{pH}$ of the water was 7.2, and oxygen saturation was more than $85 \%$. All the fish were acclimatized for 2 weeks prior to the exposure test.

2.3. Acute Exposure Test. Fish were exposed to Ag-NPs for a period of $48 \mathrm{~h}$ and $96 \mathrm{~h}$, according to the OECD Test Guideline 203: Fish Acute Toxicity Test [19]. Freshwater conditions were as described in Section 2.2. The carp were exposed to Ag-NP concentrations of 25, 50, 100, and $200 \mu \mathrm{g} / \mathrm{L}$. A blank control test (without Ag-NPs) was performed at the same time and under the same exposure conditions. All the experiments were conducted in an 80-L glass tank containing $60 \mathrm{~L}$ of water, with 10 fish in each exposure tank. The water was not changed during the test.

2.4. Measurement of Enzymatic Activity and Other Biochemical Parameters. After exposure, the gills, liver, and brain of the fish were collected, frozen, and stored separately at $-20^{\circ} \mathrm{C}$ for further treatment. The samples were rinsed with $0.15 \mathrm{mM} \mathrm{KCl}$ solution and homogenized on ice with $50 \mathrm{mM}$ phosphate buffer ( $\mathrm{pH}$ 7.0). The suspension was sonicated 
TABLE 2: Size distribution of Ag-NPs measured using DLS.

\begin{tabular}{lccccc}
\hline Concentration & Mean diameter $(\mathrm{nm})$ & Coefficient of variation & Standard deviation $(\mathrm{nm})$ & Normal standard deviation & Variance \\
\hline Nominal & $12.2 \pm 10.5$ & - & - & - & - \\
$5 \mathrm{mg} / \mathrm{L}$ & 71.7 & 0.767 & 54.966 & 0.767 & 0.876 \\
$10 \mathrm{mg} / \mathrm{L}$ & 91.2 & 0.800 & 72.979 & 0.800 & 0.894 \\
\hline
\end{tabular}

in an ultrasonic bath for $30 \mathrm{~min}$ and then centrifuged at $10,000 \times \mathrm{g}$ at $4^{\circ} \mathrm{C}$ for $10 \mathrm{~min}$. The supernatant was then removed and stored at $-80^{\circ} \mathrm{C}$, prior to analysis.

GST activity was measured using a GST Tag assay kit (Novagen, Germany), in which a sample was combined with 1-chloro-2,4-dinitrobenzene substrate in the reaction buffer. The absorbance of the reaction was monitored at $340 \mathrm{~nm}$ by using a UV spectrophotometer (Tecan Infinite F200, Austria).

CAT activity was measured using the Abei method, in which $50 \mathrm{mM} \mathrm{H}_{2} \mathrm{O}_{2}$ was used as a substrate [20]. A solution of $50 \mathrm{mM}$ peroxide was prepared in $50 \mathrm{mM}$ potassium phosphate buffer. The decomposition of $\mathrm{H}_{2} \mathrm{O}_{2}$ catalyzed by catalase can be followed using UV spectroscopy on the basis of the absorbance of $\mathrm{H}_{2} \mathrm{O}_{2}$ at a wavelength of $240 \mathrm{~nm}$. The optimum $\mathrm{pH}$ for catalase activity is about 7.0.

SOD activity was measured by using an SOD assay kit (Dojindo Laboratories, Kumamoto, Japan). Total protein concentration was measured using the Bradford method, with bovine serum albumin as the standard protein [21].

Other biochemical parameters were examined in this study, namely, ammonia $\left(\mathrm{NH}_{3}\right)$, glucose (GLU), total cholesterol (TCHO), alkaline phosphates (ALP), glutamic oxaloacetic transaminase/aspartate aminotransferase (GOT/ AST), alanine aminotransferase (GPT/ALT), $v$-glutamyltransferase (GGT), albumin (ALB), blood urea nitrogen (BUN), creatinine (CRE), and total bilirubin (TBIL).

2.5. Histopathology. After exposure, the skin, gills, and liver of the carp were dissected and fixed in Bouin's solution for $12 \mathrm{~h}$ or overnight. Subsequently, these samples were washed with water and then dehydrated using a graded ethanol series $(70 \%, 75 \%, 80 \%, 90 \%$, and 100\%). The samples were embedded in paraffin at $62^{\circ} \mathrm{C}$ and sectioned at a thickness of $5 \mu \mathrm{m}$ by using a precision microtome (MT-990; RMC Products, USA). The sections were stained using the hematoxylin and eosin (H\&E) staining method with Alcian blue and the periodic acid-Schiff (AB-PAS) reaction. An Olympus BX-51 light microscope (Olympus Corp., Japan) coupled with an ARTCAM-150 PIII digital camera was used to examine any abnormalities in the samples.

2.6. Statistical Analysis. Triplicates of all samples were exposed to Ag-NPs for statistical purposes. Data were calculated and analyzed using Excel (Microsoft Corporation, WA, USA) software and plotted using Sigma Plot (SPSS Inc., CA, USA). The differences between the samples and blank controls were evaluated using one-way analysis of variance and the Student's $t$-test. The difference was considered significant when $P<0.05$.
TABLE 3: Concentration of Ag-NPs ( $\mu \mathrm{g} / \mathrm{L})$ measured using ICP-MS.

\begin{tabular}{lccc}
\hline $\begin{array}{l}\text { Nominal } \\
\text { concentration }\end{array}$ & $\begin{array}{c}\text { Measured } \\
\text { concentration }\end{array}$ & RSD (\%) & Element \\
\hline 1.56 & 0.87 & 12.62 & $\mathrm{Ag}$ \\
3.13 & 1.33 & 6.52 & $\mathrm{Ag}$ \\
6.25 & 3.09 & 6.26 & $\mathrm{Ag}$ \\
12.5 & 7.70 & 8.94 & $\mathrm{Ag}$ \\
25.0 & 14.65 & 4.18 & $\mathrm{Ag}$ \\
50.0 & 34.94 & 10.57 & $\mathrm{Ag}$ \\
\hline
\end{tabular}

2.7. Data Analysis. RNA extraction and DNA microarray analysis were performed according to the protocol previously described by Lee et al. [18]. Subio platform ver. 1.6 was used for the expression analysis. The sequences of each clone ID were aligned on the basis of sequence homology by using the basic local alignment search tool (BLAST) in the National Center for Biotechnology Information database [22]. The translated nucleotide sequences were compared with the protein databases by using the BLASTX analysis software.

\section{Results}

3.1. Ag-NPs Properties. The size distribution and morphology of Ag-NPs were examined using TEM and DLS. As shown in Figure 1, Ag-NPs became agglomerated in the solution, and the nominal size measured using TEM was $\sim 12 \mathrm{~nm}$. However, the mean size of the agglomerated particles varied as much as several hundred nanometers. The DLS results showed that the mean diameter of Ag-NPs at $5 \mathrm{mg} / \mathrm{L}$ and $10 \mathrm{mg} / \mathrm{L}$ was $\sim 70 \mathrm{~nm}$ and $\sim 90 \mathrm{~nm}$, respectively (Table 2). However, particles with a diameter of less than $20 \mathrm{~nm}$ were frequently observed in the solution. Elemental Ag was measured using ICP-MS, and the results are shown in Table 3, with relative standard deviations ranging around $10 \%$. In general, Ag-NPs were well dispersed in DI water solution, with some agglomeration and aggregation.

3.2. Antioxidant Enzymatic Activities. The antioxidant enzymes, including those of GST, CAT, and SOD, were measured, and the results are shown in Figures 2, 3, and 4. Generally, enzymatic activities changed with different Ag-NP concentrations. After $48 \mathrm{~h}$ of exposure, GST activities in the liver, gills, and brain were not significantly different than that observed when the fish were exposed to $25 \mu \mathrm{g} / \mathrm{L}$ and $50 \mu \mathrm{g} / \mathrm{L}$ of Ag-NPs (Figure 2(a)). When the concentration of Ag-NPs increased to $100 \mu \mathrm{g} / \mathrm{L}$ and $200 \mu \mathrm{g} / \mathrm{L}$, GST activity was more significantly reduced in the gills than in the liver 


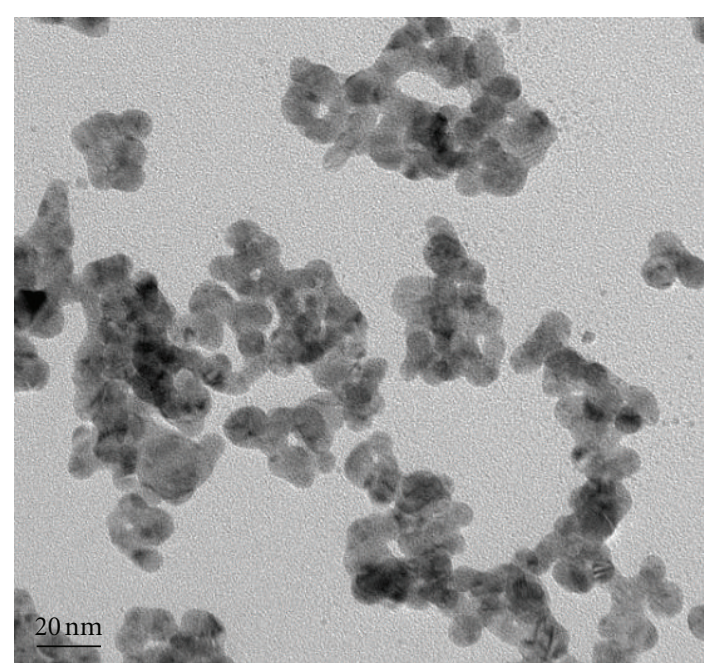

Specimen:

Operator:

Voltage: $200 \mathrm{kV}$

Microscope name:

Name: US10001

Total magnification: X936000 Exposure time: 1

Indicated magnification: X100000

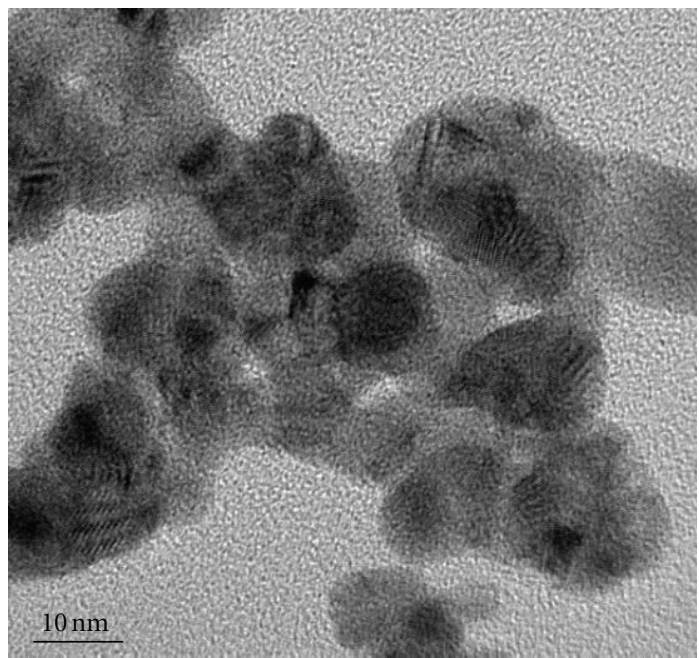

Specimen:

Operator:

Image name: $2-8$

Resolution: $2048 \times 2048$

Acquisition date: $12 / 8 / 2009$

Acquisition time: 7:48:23

Collection number:

Microscope name:

Name: US10001

Total magnification: X2850000 Exposure time: 0.5

Indicated magnification: X300000

(a)

(b)

Figure 1: TEM images of Ag-NPs used in the experiments.

and brain. After $96 \mathrm{~h}$ of exposure, GST activity was elevated in the liver; this was correlated with an increase in Ag-NP concentration in the media (Figure 2(b)). GST activity in liver samples exposed to $100 \mu \mathrm{g} / \mathrm{L}$ and $200 \mu \mathrm{g} / \mathrm{L}$ was about $190 \%$ higher than that observed in the control fish. In comparison, GST activity in the brain and gills declined at $200 \mu \mathrm{g} / \mathrm{L}$ and was significantly lower than that in the control group. GST activity in the liver of fish after $96 \mathrm{~h}$ of exposure was also higher than that in fish subjected to $48 \mathrm{~h}$ of exposure, especially at $100 \mu \mathrm{g} / \mathrm{L}$ of Ag-NPs. After $96 \mathrm{~h}$ of exposure, GST activity was also higher in the liver than in the brain and gills.

As shown in Figure 3, higher levels of CAT activity were detected in the liver than in the brain and gills of the experimental fish. Similar to GST activity, CAT activity in the liver changed at different Ag-NP concentrations, but it remained relatively stable in the brain and gills. No significant difference in CAT activity was recorded between the brain and gills. CAT concentrations in the liver of the fish after $48 \mathrm{~h}$ of exposure showed no significant difference to that in the control group (Figure 3(a)). However, CAT activity declined at lower Ag-NP concentrations (i.e., $25 \mu \mathrm{g} / \mathrm{L}$ and $50 \mu \mathrm{g} / \mathrm{L}$ ) and increased at higher Ag-NP concentrations (i.e., $100 \mu \mathrm{g} / \mathrm{L}$ and $200 \mu \mathrm{g} / \mathrm{L}$ ). However, after $96 \mathrm{~h}$ of exposure, CAT activity was significantly reduced in the liver at $25 \mu \mathrm{g} / \mathrm{L}$ and $50 \mu \mathrm{g} / \mathrm{L}$, recovered at $100 \mu \mathrm{g} / \mathrm{L}$, and then decreased again at $200 \mu \mathrm{g} / \mathrm{L}$ of Ag-NPs (Figure 3(b)).

SOD activity differed from that of GST and CAT in that it was relatively stable in all examined tissues (Figure 4). However, similar to GST and CAT, higher levels of SOD activity were detected in the liver than in the brain and gills. There was no significant difference in SOD levels among the different exposure groups.

3.3. Biochemical Parameters in the Blood. In this study, the biochemical parameters in the blood of the exposed fish were also analyzed to understand the changes in metabolism and fish response to the stressor (i.e., Ag-NPs). Detailed information was published in our previous study [18], where the concentration of biochemical parameters such as ammonia $\left(\mathrm{NH}_{3}\right)$, glutamic oxaloacetic transaminase (GOT), and total cholesterol (TCHO) declined at the beginning of exposure and gradually recovered with increase in Ag-NP concentration. Other parameters such as alanine aminotransferase (GPT), $v$-glutamyl transferase (GGT), albumin (ALB), blood urea nitrogen (BUN), creatinine (CRE), and total bilirubin (TBIL) remained stable or fluctuated around the levels of the control groups, without any significant difference. In comparison, alkaline phosphatase (ALP) levels increased with increase in Ag-NPs concentration. After reaching the highest concentration when exposed to $50 \mu \mathrm{g} / \mathrm{L}$ of Ag-NPs, ALP concentration began to decline when the fish were exposed to $100 \mu / \mathrm{L}$ and $200 \mu \mathrm{g} / \mathrm{L}$ of Ag-NPs. However, these biochemical parameters in blood of common carp were not significantly changed.

3.4. Histopathology. Histopathology of the skin, gills, and liver of the fish was observed. The results are shown in Figures 5, 6, and 7. The histological structure of the skin (Figure 5) is composed of an epidermal layer and a dermal 


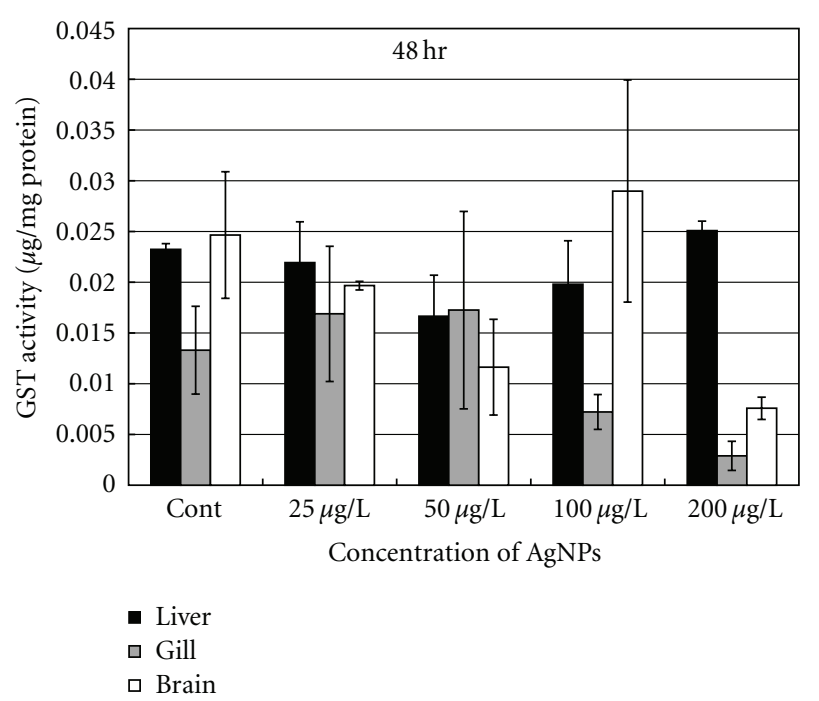

(a)

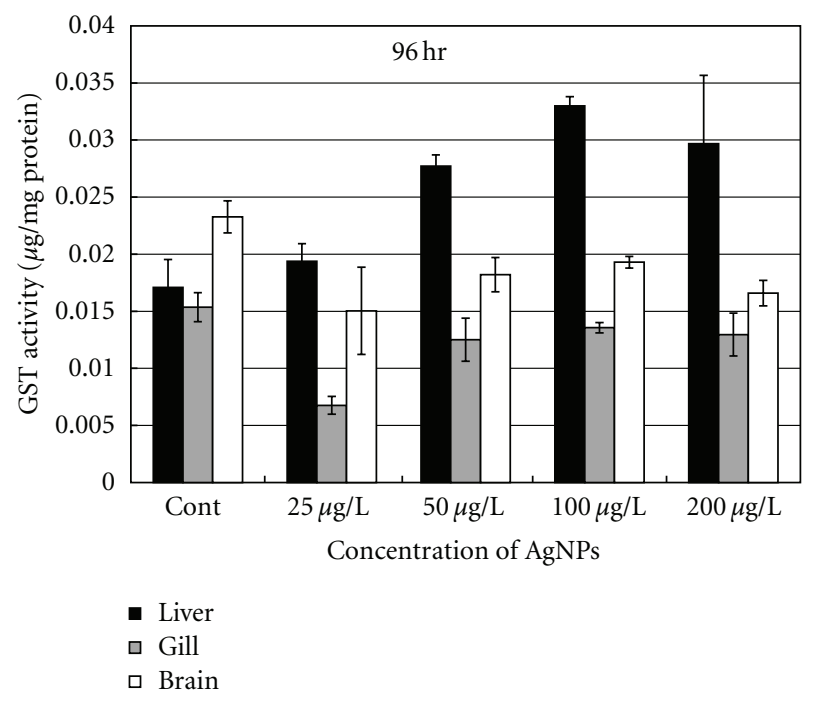

(b)

FIGURE 2: GST activity in different organs of the common carp exposed to various concentrations of Ag-NPs at (a) $48 \mathrm{~h}$ and (b) $96 \mathrm{~h}$.

layer. The epidermis is the outermost layer of the skin, where the epithelial and secretory cells are distributed. Secretory cells comprise club and mucous cells. When dyed with H\&E stain, the vacuolated mucous cells appeared as blank circles or elliptical in shape and were marked with a blue color (color index 313C) as a result of the AB-PAS ( $\mathrm{pH} 2.5$ ) reaction. Vacuolated club cells also appeared elliptical in shape when using the AB-PAS ( $\mathrm{pH} 2.5)$ reaction.

As illustrated in Figure 5(a), the skin histology of the control fish showed that normal-sized mucous cells (Mcs) were present, with appropriate amounts of club cells (Ccs) in the epidermal layer. Exposure to $50 \mu \mathrm{g} / \mathrm{L}$ of Ag-NPs (Figure 5(b)) increased the size and number of mucous cells marked with Alcian blue by using the AB-PAS ( $\mathrm{pH} 2.5$ ) positive reaction. On increasing the level of exposure to

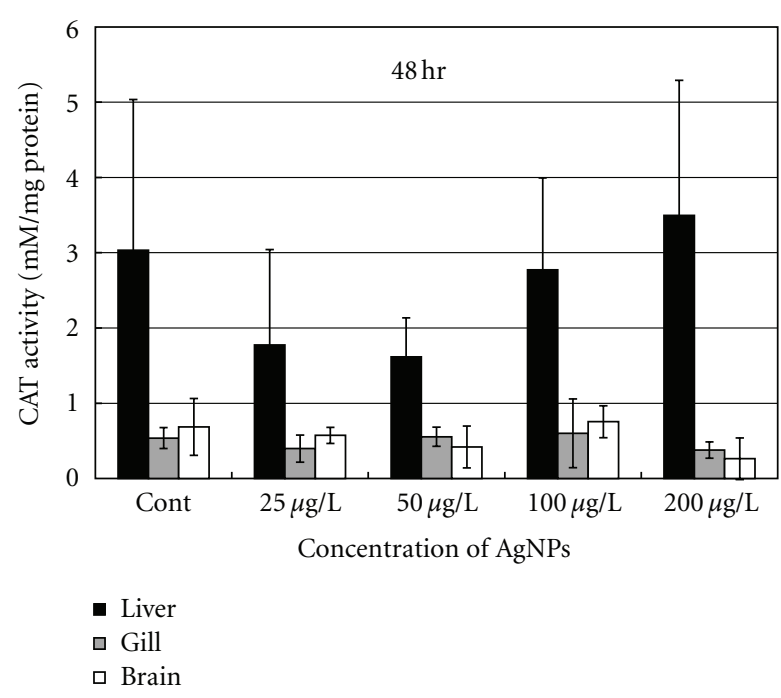

(a)

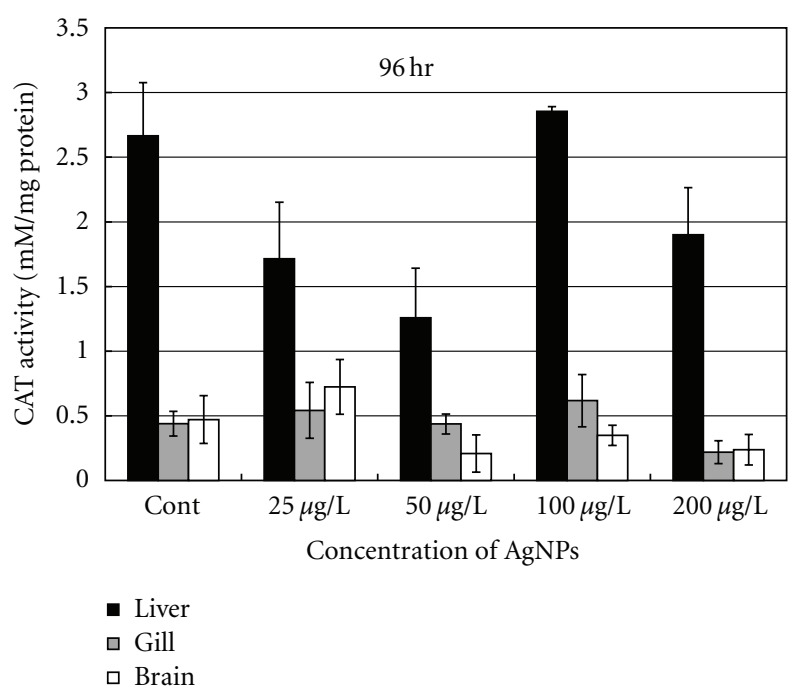

(b)

Figure 3: CAT activity in different organs of the common carp exposed to various concentrations of Ag-NPs at (a) $48 \mathrm{~h}$ and (b) $96 \mathrm{~h}$.

$100 \mu \mathrm{g} / \mathrm{L}$ of Ag-NPs, the amount of club cells in the epidermal layer significantly increased. The size of the mucous cells was also larger than those of the control fish (Figure 5(c)). At $200 \mu \mathrm{g} / \mathrm{L}$ of Ag-NPs, hyperplasia ( $\star$ ) was frequently recorded in the epidermal layer of the exposed samples (Figure 5(d)).

Carp have one pair of gills on each side of the body, like other teleosts. The gill raker is lined up at the front of the gill arch. As shown in Figure 6(a), numerous gill lamellae are lined up along either side of the gill filament. The gill filament consists of a cartilaginous support, which is a multilayered epithelium. In comparison, the gill lamella is surrounded by simple squamous cells from the outer layer. Pillar cells are present between the capillaries of the lamella. Secretory cells consist of chloride and mucous cells. After staining with H\&E, vacuolated mucous cells appeared as blank circles or 


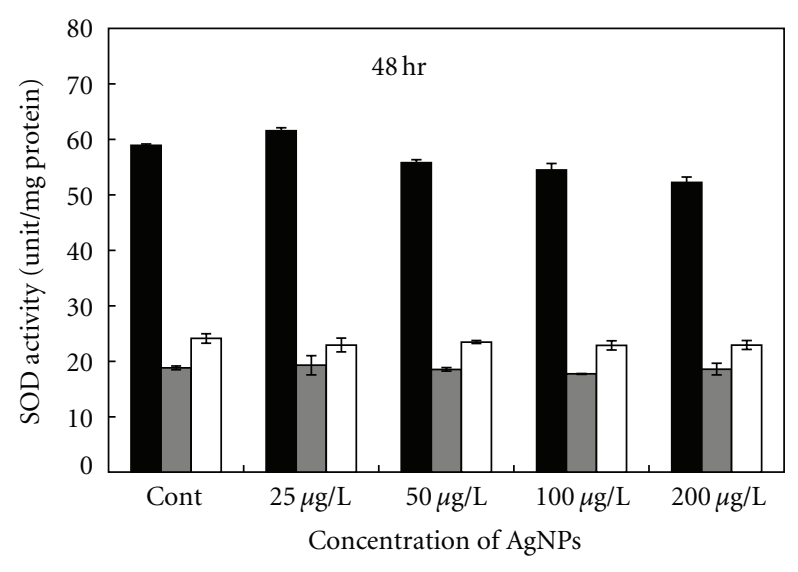

- Liver

$\square$ Gill

Brain

(a)

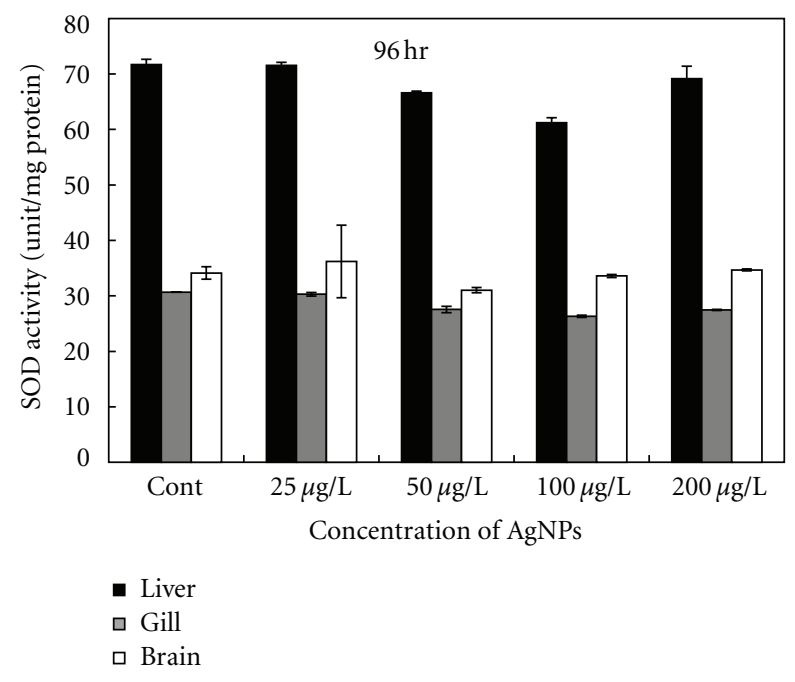

(b)

FIGURE 4: SOD activity in different organs of the common carp exposed to various concentrations of Ag-NPs at (a) $48 \mathrm{~h}$ and (b) $96 \mathrm{~h}$.

elliptical in shape but were marked with a blue color (color index 313C) as a result of the AB-PAS ( $\mathrm{pH} 2.5$ ) reaction.

As shown in Figure 6(b), exposure to $50 \mu \mathrm{g} / \mathrm{L}$ of $\mathrm{Ag}$ NPs caused the bifurcation of the filament (black arrow). Figure 6(c) shows an increased number of mucosa cells (black arrow) in the gills of the fish exposed to $100 \mu \mathrm{g} / \mathrm{L}$ of Ag-NPs. The exposure of the fish to $200 \mu \mathrm{g} / \mathrm{L}$ of AgNPs caused hyperplasia $(\star)$ of the epithelium in the lamella; this finding was not observed in the control group (Figure 6(d)). This phenomenon was also recorded at other concentrations of Ag-NPs, but it was most clearly observed at a concentration of $200 \mu \mathrm{g} / \mathrm{L}$.

The liver of carp consists of numerous lobules, along with various bile ducts, capillaries, and the pancreas. Hepatocytes from the control group were clearly observed to have a round polygon shape with a nucleus (Figure 7(a)). Exposure to $100 \mu \mathrm{g} / \mathrm{L}$ of Ag-NPs caused extreme atrophy of the hepatocyte nucleus in the liver of the fish (Figure 7(b)). Fish exposed to $200 \mu \mathrm{g} / \mathrm{L}$ of Ag-NPs showed atrophy of the hepatocyte nucleus and an accumulation of eosinophilic granules (color index 2415C, black arrowhead) in the liver (Figure 7(c)).

3.5. TEM Analysis of Tissues. As shown in Figure 8, AgNPs penetrated the skin of common carp after $96 \mathrm{~h}$ of exposure, regardless of particle concentrations. Ag-NPs were present in every layer of the skin, including the epithelium (Figure 8(b)), epidermis (Figure 8(a)), and mitochondrion (Figure $8(\mathrm{c})$ ). Ag-NPs penetration occurred with single and agglomerated particles. The particles stayed either in the junctions of the cells, on the cell membrane, or inside the cell. Penetration by a large number of Ag-NPs in the skin would result in damaging the cell junction, membrane, or other cell structures, depending on the size and concentration of the particles. The penetration of large agglomerations of particles into the skin (as shown in Figure 8(b)) may destroy the structure and connection between the skin layers, while small amounts of single particles (as shown in Figure 8(c)) may stick on the membrane of cells, causing them to malfunction.

In this study, the penetration of Ag-NPs in the gills of common carp after exposure was evaluated. Figure 9 shows the presence of nanoparticles in the gill structures, including the gill lamella, the nucleus of gill cells, and blood corpuscles. If the skin is the first defensive structure of the fish body, the gill is an important organ that allows gaseous transfer and filtration of foreign materials. Ag-NPs were detected in every part of the gill at varying levels of penetration, such as between blood corpuscles and inside cell nuclei. The effects of nanoparticles on cell function might be more severe because of deep penetration. The presence of nanoparticles in different parts of the gills indicated that common carp is significantly affected by exposure to Ag-NPs. The effects may be directly expressed by damage to the tissue structure or indirectly expressed through abnormal levels of other biochemical markers.

In this study, we also investigated the penetration of Ag-NPs into other important organs of the fish, including the brain and liver. The results are shown in Figure 10, indicating that particles entered the brain and liver of common carp exposed to $200 \mu \mathrm{g} / \mathrm{L}$ of Ag-NPs for $96 \mathrm{~h}$. As shown in Figure 10, the particles were able to penetrate deep into the brain cells. This result indicated that the particles were carried through the body of the fish by the circulation of blood, subsequently accumulating in different important organs. Liver is an important organ of the body that facilitates the detoxification of substances, whereas the brain controls the activity of the whole body. Damage to these organs may result in the malfunction of fish activities and, more seriously, may cause fish mortality. The findings of this study are comparable to those of a previous report by Park et al. [23, 24], who observed that titanium dioxide nanoparticles caused chronic inflammatory disease and oxidative stress by intratracheal instillation in mice. 


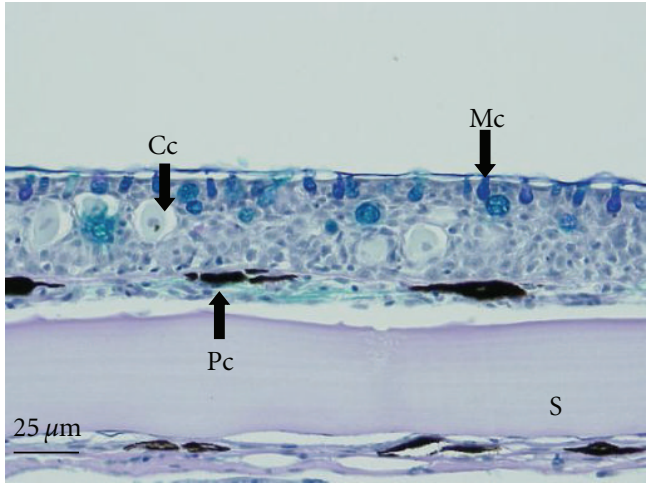

(a)

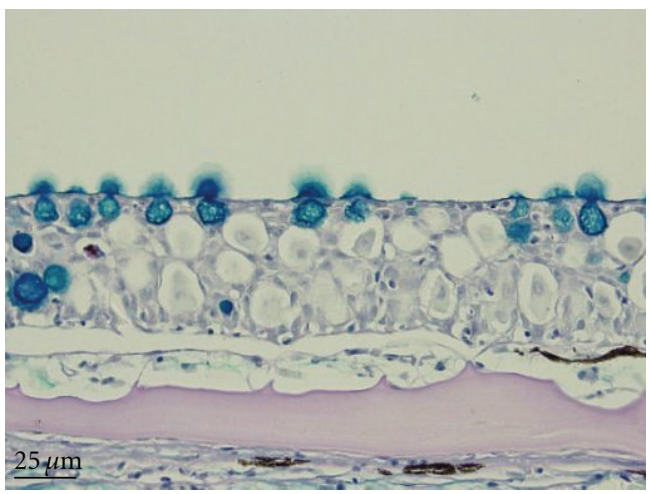

(c)

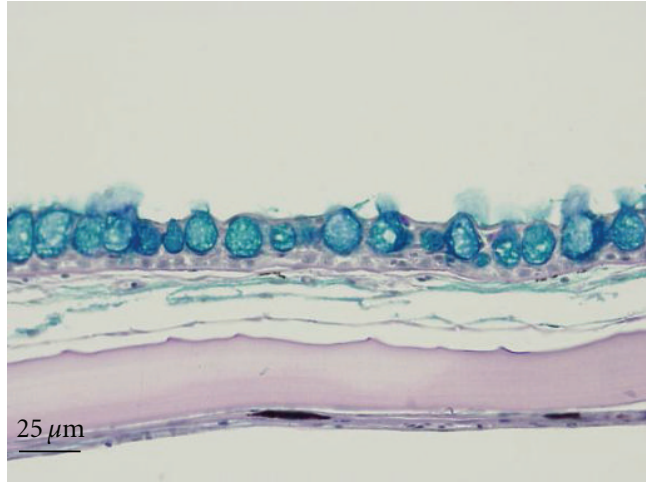

(b)

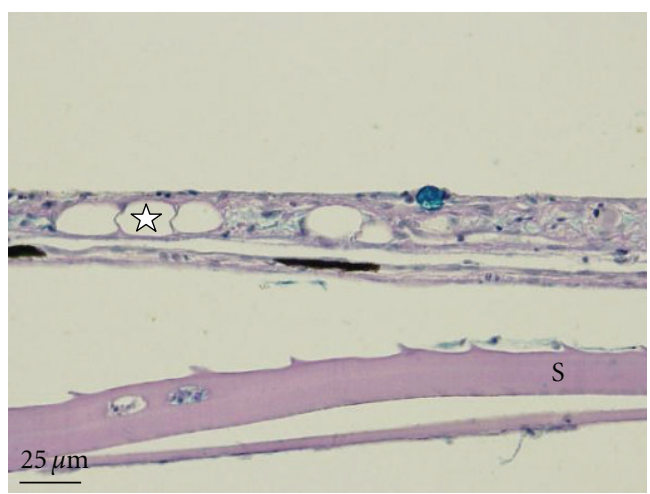

(d)

FIgURE 5: Histological changes in the skin of the common carp (Cyprinus carpio) exposed to Ag-NPs for $96 \mathrm{~h}$. (a) Control. (b) 50 $\mu \mathrm{g} / \mathrm{L}$. Increase in mucous cells shown by staining with Alcian blue. (c) $100 \mu \mathrm{g} / \mathrm{L}$. Increase in club cells. (d) $200 \mu \mathrm{g} / \mathrm{L}$. Vacuolation of the epithelium $(\star)$. Cc: club cell, Mc: mucous cell, Pc: pigment cell, S: scale. AB-PAS (pH 2.5) reaction.

3.6. Gene Expression Profiling of Common Carp Exposed to AgNPs. Alteration of the level of genomic expression towards $100 \mu \mathrm{g} / \mathrm{L}$ of Ag-NPs exposure for $96 \mathrm{~h}$ in the liver of the common carp was analyzed using the DNA microarray method. In response to Ag-NP exposure, there was a 2-fold upregulation and downregulation of 502 genes and 1,850 genes, respectively. Differentially expressed genes ( $>2$-fold, $P$ $<0.05)$ with defined functions are summarized in Table 4. Among the upregulated genes, 12 genes, including that for the myc associate protein $\mathrm{X}$ (MAX), were shown to be involved in cell apoptosis, proliferation, protein synthesis, and energy production (Table 4). Generally, MAX has been known to participate in cell death and cell proliferation, with the interaction of myc [25]. Among the downregulated genes, 11 genes, including that for glutathione peroxidase $4 \mathrm{a}$ $(\mathrm{GPx}), \mathrm{GST}$, and the retinol binding protein (RBP), were shown to play a role in oxidative stress response, cellular defense, cell migration, detoxification, and fibrinolysis (Table 4). Both GPx and GST have protective effects against oxidative stress (caused by the reactive oxygen species ROS), while RBP has a major function in retinol metabolism $[26,27]$. Our findings indicate that Ag-NPs might cause biological malfunctions or dysregulation in cellular processes, including cell death, proliferation, and resistance to oxidative stress. Ag-NPs also contribute towards changing the gene expression of particular sets of genes, which might be considered as plausible biomarkers of Ag-NPs toxicity.

\section{Discussion}

Because of its strong antibacterial activity, Ag is regularly used in preservative and hygiene products. Ag-NPs, categorized at a nanoscale, are expected to possess many physical and chemical properties that are different from those of their bulk particles. However, the novel properties of these particles require study, particularly because of their potential effects when exposed to organisms, including human beings. One of the novel properties of nanoparticles in general (AgNPs in particular) is their minute diameter, in comparison with that of their bulky counterparts $[28,29]$. Because of the ultrafine particle-size, Ag-NPs may penetrate deep into the organs and, therefore, alter normal metabolic and bodily functions. Fortunately, naturally occurring nanoparticles usually form aggregations, agglomerations, or complexes with other substances, such as natural organic materials. These complexes and/or aggregations/agglomerations reduce the size advantage of nanoparticles, thus reducing their toxicity or other adverse effects on aquatic organisms. To evaluate the impact of other materials on the toxicity of nanoparticles, synthesized particles with coated materials have been used 


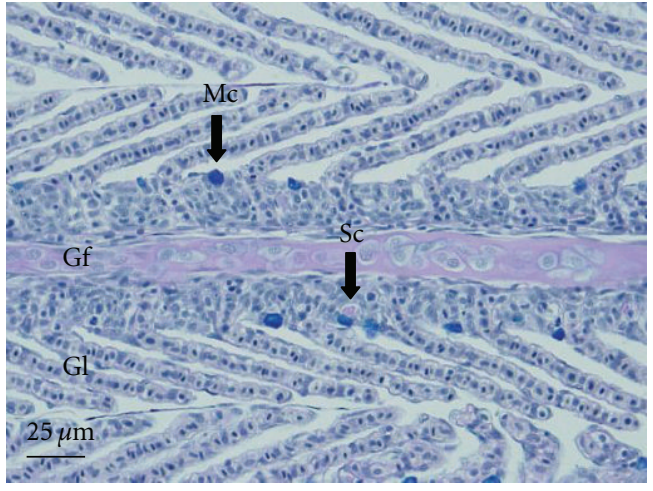

(a)

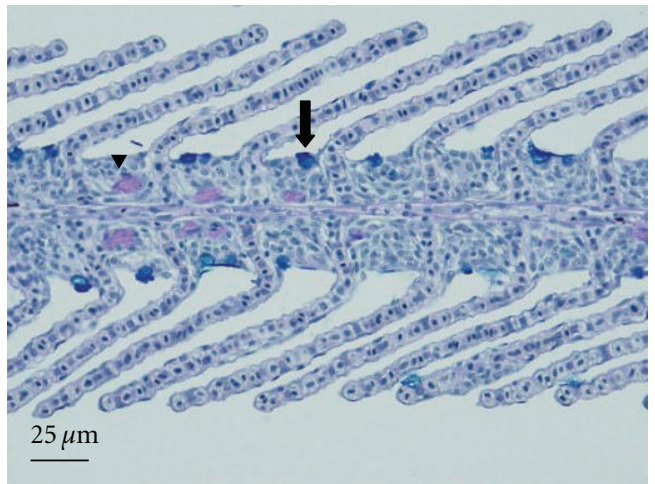

(c)

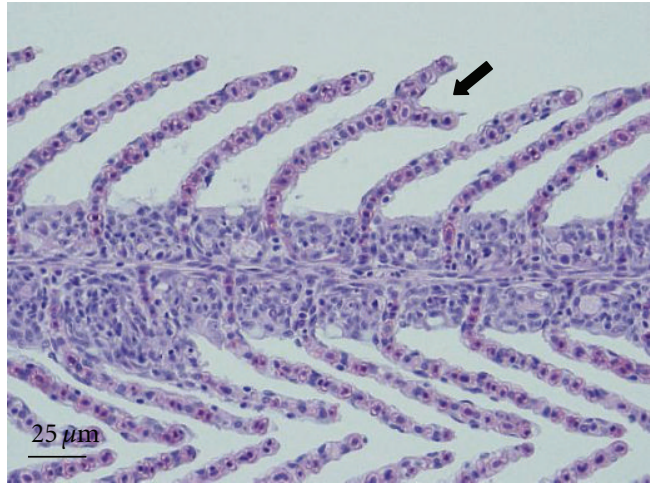

(b)

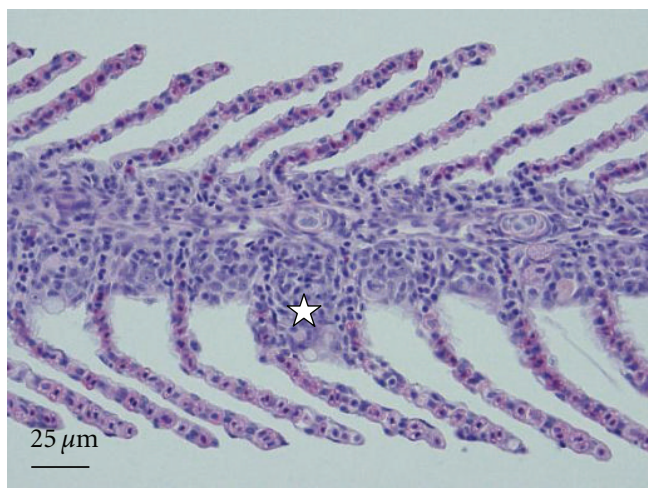

(d)

Figure 6: Histological changes in the gill of the common carp (Cyprinus carpio) exposed to Ag-NPs for 96 h. (a) Control. Mc: mucous cell, Gf: gill filament, Gl: gill lamella, Sc: secretion cell. AB-PAS (pH 2.5) reaction. (b) $50 \mu \mathrm{g} / \mathrm{L}$. Bifurcation of the filament. H\&E stain. (c) $100 \mu \mathrm{g} / \mathrm{L}$. Increase in mucous cells. AB-PAS (pH 2.5) reaction. (d) $200 \mu \mathrm{g} / \mathrm{L}$. Hyperplasia of the lamellar epithelium ( ). H\&E stain.

in various experiments. Stabilizers of nanoparticles include ligands, surfactants, and polymers with different functional groups, such as $-\mathrm{COOH}$ and $-\mathrm{NH}_{2}$. Several studies on the toxicity of stabilized Ag-NPs have been performed [17]. However, the toxicity and adverse effects of Ag-NPs capped with natural organic substances remain unclear.

In this study, we used citric acid as a capping agent to stabilize Ag-NPs in solution. As shown in Table 1, this stabilizer keeps the particles well separated, with a nominal size of $10 \sim 20 \mathrm{~nm}$. In addition, citric acid is a common organic substance in the natural environment and our daily life (e.g., fruit juice). Hence, developing an understanding of the mechanisms and effects of citrate-Ag-NPs would contribute towards evaluating the fate and impacts of AgNPs in environmental matrixes.

The antioxidant enzyme system is responsible for the elimination of oxidative stress during the early stage of the body's defensive mechanism. This system comprises several enzyme classes, including GST, CAT, and SOD. Abnormal changes in enzymes reflect the level of oxidative stress encountered by the body. In the current study, higher levels of GST, CAT, and SOD activities were detected in the liver compared to the brain and gills. This is because the liver is the major detoxification organ of the body. In this study, after $48 \mathrm{~h}$ of exposure, GST and CAT activities in the liver were observed to vary, but they generally declined at lower Ag-NP concentrations and recovered at higher AgNP concentrations. GST is known for its catalysis function in the reduction process of glutathione (GSH), in which endogenous and xenobiotic chemicals are detoxified [30]. The reduction of GST occurs as a result of the overutilization of existing enzymes to overcome oxidative stress caused by Ag-NPs, which causes an increase in GSH concentration in specific organs [31]. In this study, the carp showed a significant reduction in GST activity in the gills after $48 \mathrm{~h}$ of exposure to $200 \mu \mathrm{g} / \mathrm{L}$ of Ag-NPs, but recovered after $96 \mathrm{~h}$ of exposure (Figure 2).

Oxidative stress increased with a reduction in GST concentration; this may cause the development of toxic effects or even carcinogenic effects. However, higher AgNP concentrations may trigger the production of enzymes to counteract the severe effects of the particles. Hence, an increase in GST concentration may be used as an indicator for the depletion of GSH in detoxification processes. However, the correlation between GSH and GST requires further study.

The main function of CAT is to catalyze the decomposition of $\mathrm{H}_{2} \mathrm{O}_{2}$ [32]. In this study, the activity of CAT detected in the liver was significantly higher than that in the brain and gills (Figure 3). CAT concentration in the liver 


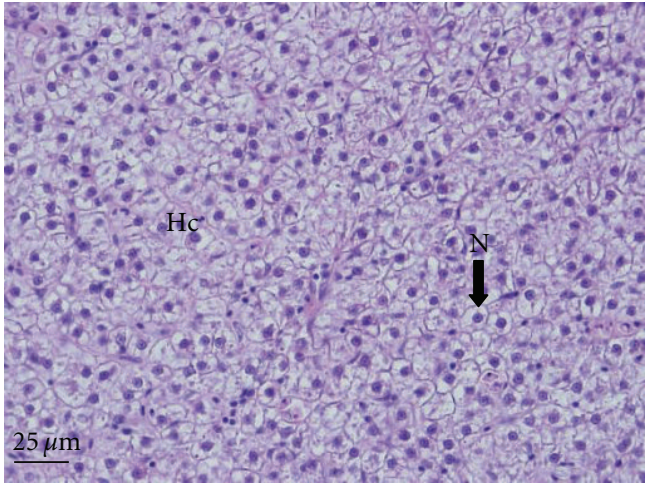

(a)

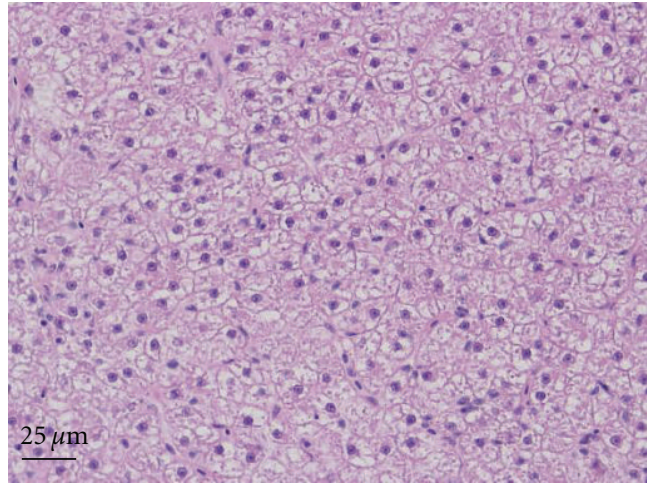

(b)

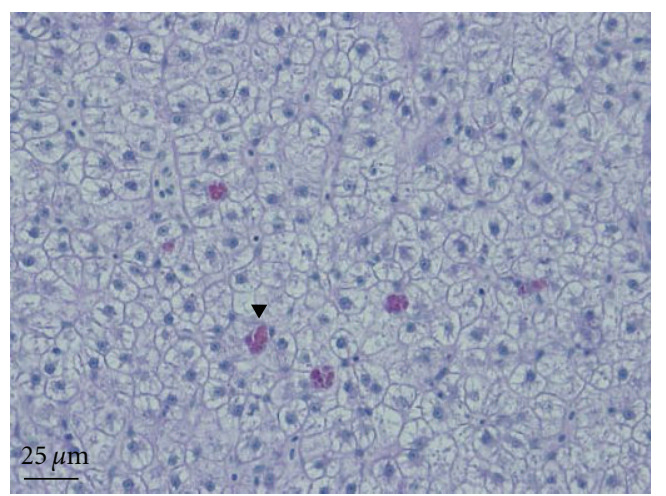

(c)

FIgURE 7: Histological changes in the liver of the common carp (Cyprinus carpio) exposed to Ag-NPs for 96 h. (a) Control. AB-PAS (pH 2.5). (b) $100 \mu \mathrm{g} / \mathrm{L}$. Atrophy of the hepatocyte nucleus. H\&E stain. (c) $200 \mu \mathrm{g} / \mathrm{L}$. Accumulation of eosinophilic granules (arrow head). AB-PAS (pH 2.5). Hc: hepatocyte, N: nucleus.

also declined when the fish were exposed to lower Ag-NP concentrations and then recovered with an increase in Ag-NP concentrations. However, after $96 \mathrm{~h}$ of exposure at $200 \mu \mathrm{g} / \mathrm{L}$ of Ag-NPs, CAT levels in all the examined organs (i.e., brain, liver, and gills) were significantly lower than those in the control group, as well as for fish exposed to $100 \mu \mathrm{g} / \mathrm{L}$ of Ag-NPs (Figure 3(b)). This phenomenon was not observed during the $48 \mathrm{~h}$ test under the same concentration. These results indicate that the impact of Ag-NPs on the fish was more severe under longer periods of exposure. The results of CAT and GST activities also indicated that when the fish were exposed to short periods ( $48 \mathrm{~h}$ ) of Ag-NPs at a concentration of $<100 \mu \mathrm{g} / \mathrm{L}$, oxidative stress mainly occurred in the liver.

SOD is an enzyme that primarily catalyzes the dismutation of superoxide radicals. Thus, the depletion of this enzyme may indicate that the antioxidant defense system is overwhelmed [33]. In the present study, SOD activity in the brain and gills was not significantly different between the control and exposed fish. However, SOD activity was significantly lower in the liver of fish exposed to $200 \mu \mathrm{g} / \mathrm{L}$ of Ag-NPs compared to the liver of fish in the control group (Figure 4(a)). It has been suggested that the antioxidant defense system of the liver is severely affected at this concentration, as illustrated by the reduction of other enzymes (i.e., CAT and GST) in the liver of fish exposed to lower
Ag-NPs concentrations. However, after $96 \mathrm{~h}$ of exposure, SOD activity returned to the control level (Figure 4(b)). Hence, we hypothesize that GST and CAT were produced in sufficient quantities to counteract the oxidative stress caused by Ag-NPs. However, the correlation and combined effects of GST, CAT, and SOD, as well as other antioxidant enzymes, require further study.

As shown in the results of the biochemical analysis, the concentrations of $\mathrm{NH}_{3}$ and GOT declined and recovered, similar to that observed for other antioxidant enzymes (e.g., CAT and GST). It is known that $\mathrm{NH}_{3}$ in the blood is associated with hepatic detoxification (i.e., the urea cycle). Therefore, fluctuations in blood $\mathrm{NH}_{3}$ concentrations may be related to the antioxidant defense system. Our previous study showed that BUN concentration also decreased at $200 \mu \mathrm{g} / \mathrm{L}$ of Ag-NPs; hence, changes in the enzyme system may alter the capability of urine transformation. However, other biochemical parameters were not significantly altered. Along with slight fluctuations in antioxidant enzymes, this result indicates that $<200 \mu \mathrm{g} / \mathrm{L}$ of Ag-NPs exposure did not have a severe effect on the fish.

The histological analysis of the tissues also showed that Ag-NPs have potential adverse effects on exposed fish. As shown in Figure 5, the histopathology of the skin samples showed an increase in the number and size of mucous and 


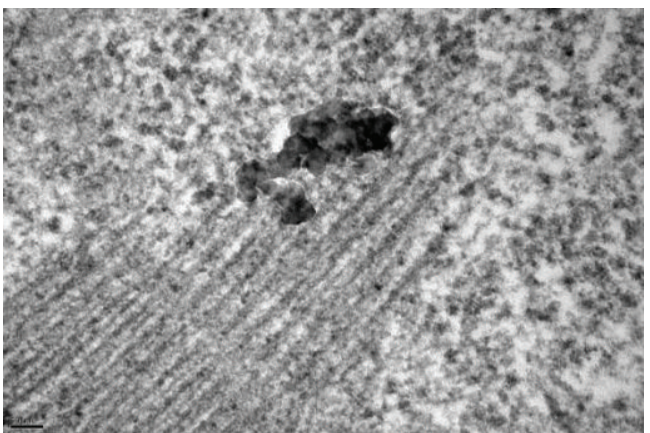

(a)

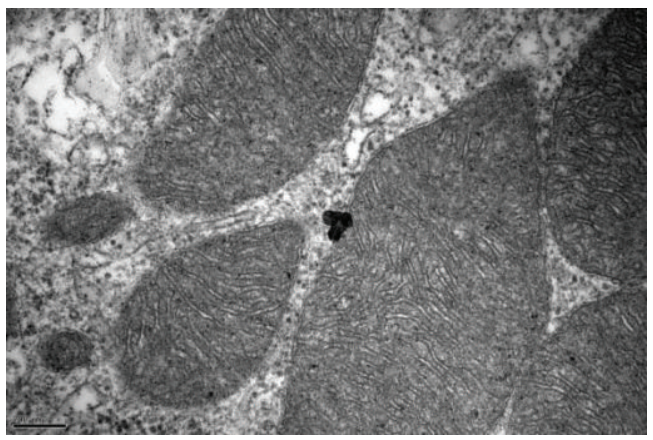

(c)

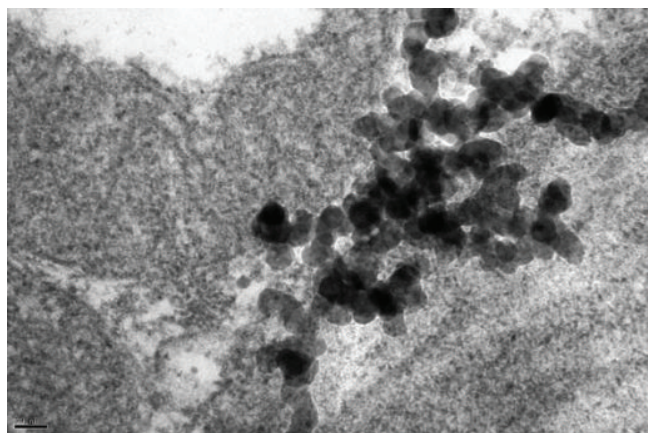

(b)

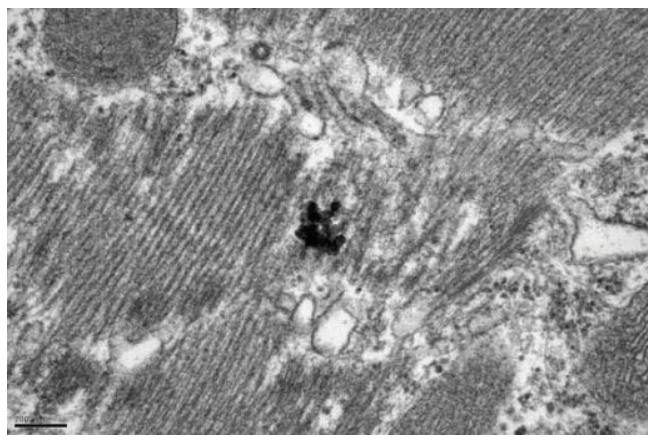

(d)

Figure 8: TEM image of the skin of the common carp (Cyprinus carpio) exposed to Ag-NPs for $96 \mathrm{~h}$. (a) $25 \mu \mathrm{g} / \mathrm{L}$. Epidermis. (b) $50 \mu \mathrm{g} / \mathrm{L}$. Epithelium. (c) $100 \mu \mathrm{g} / \mathrm{L}$. Mitochondrion in epithelium. (d) $200 \mu \mathrm{g} / \mathrm{L}$. Epithelium.

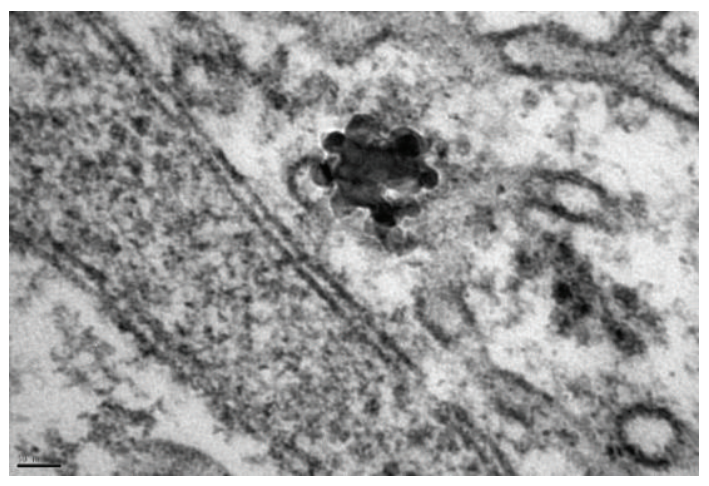

(a)

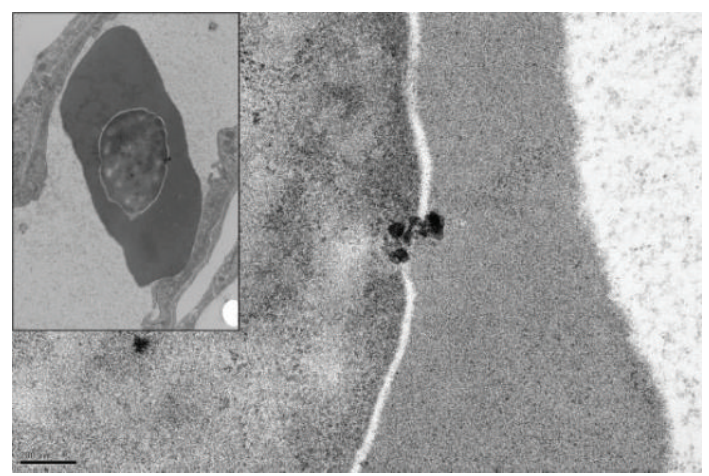

(c)

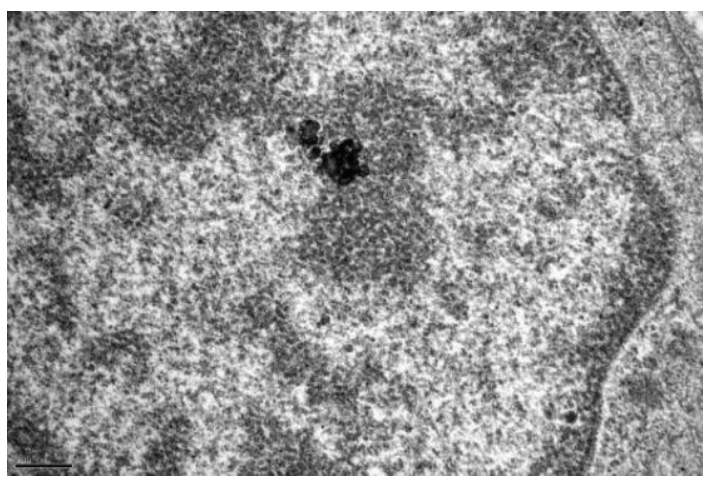

(b)

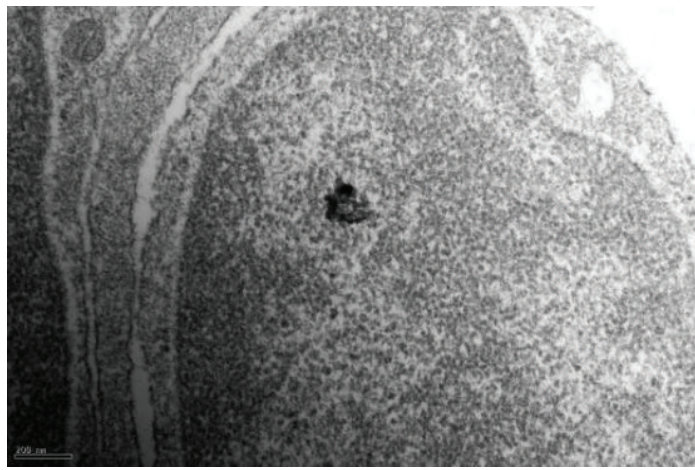

(d)

Figure 9: TEM image of the gill of the common carp (Cyprinus carpio) exposed to Ag-NPs for $96 \mathrm{~h}$. (a) $25 \mu \mathrm{g} / \mathrm{L}$. Gill lamella. (b) $50 \mu \mathrm{g} / \mathrm{L}$. Nucleus. (c) $100 \mu \mathrm{g} / \mathrm{L}$. Blood corpuscle. (d) $100 \mu \mathrm{g} / \mathrm{L}$. Nucleus. 


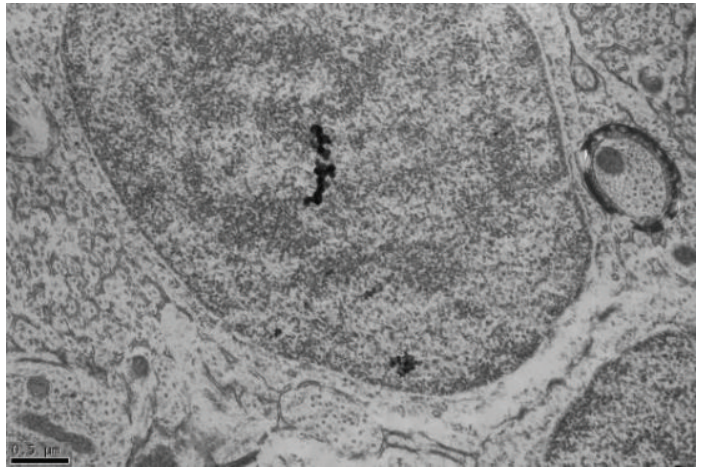

(a)

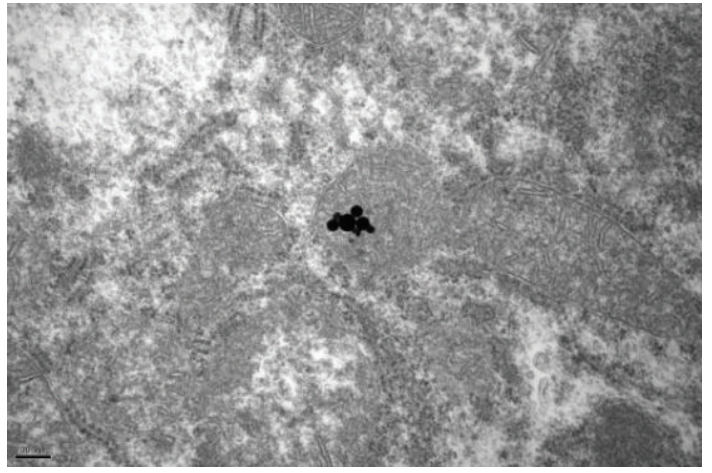

(b)

Figure 10: TEM image of the brain (a) and liver (b) of the common carp (Cyprinus carpio) exposed to $200 \mu \mathrm{g} / \mathrm{L}$ of Ag-NPs for $96 \mathrm{~h}$.

TABLE 4: Genes were altered 2-fold in response to Ag-NPs in the common carp, which were modified from our previous study [18] $(P<$ $0.05)$.

\begin{tabular}{|c|c|c|c|c|c|}
\hline $\begin{array}{l}\text { GenBank } \\
\text { accession no. }\end{array}$ & Fold change & $P$ Value & Description & Species & $E$ value \\
\hline \multicolumn{6}{|l|}{ Upregulated } \\
\hline ADO27831.1 & 2.93 & 0.00 & NADH dehydrogenase 1 subunit c2 & Ictalurus furcatus & $7.00 E-62$ \\
\hline ACI66030.1 & 2.15 & 0.00 & ATP synthase subunit $\mathrm{O}$, mitochondrial precursor & Salmo salar & $4.00 E-77$ \\
\hline BAA99395.1 & 2.03 & 0.00 & myc associate protein $X$ & Cyprinus carpio & $3.00 E-87$ \\
\hline BAE78447.1 & 2.32 & 0.01 & Cytochrome b & Cyprinus carpio & $5.00 E-77$ \\
\hline CAB60196.1 & 3.77 & 0.00 & Putative natural resistance-associated macrophage protein & Cyprinus carpio & 0 \\
\hline AAR10978.1 & 2.78 & 0.00 & Mitochondrial uncoupling protein 2 & Squalius cephalus & 0 \\
\hline AAD24542.1 & 4.65 & 0.00 & MHC class II-associated invariant chain & Danio rerio & $3.00 E-104$ \\
\hline CAA62498.1 & 2.02 & 0.00 & MHC class I protein & Cyprinus carpio & 0 \\
\hline BAA32797.1 & 2.64 & 0.00 & CXCR4 & Cyprinus carpio & 0 \\
\hline CAM56519.1 & 2.96 & 0.00 & Ribosomal protein S9 & Danio rerio & $2.00 E-88$ \\
\hline NP_001018426.1 & 2.32 & 0.00 & $60 \mathrm{~S}$ ribosome subunit biogenesis protein NIP7 homolog & Danio rerio & $1.00 E-93$ \\
\hline AEM37694.1 & 2.20 & 0.00 & Ribosomal protein L3 & Epinephelus bruneus & $1.00 E-24$ \\
\hline \multicolumn{6}{|l|}{ Downregulated } \\
\hline ACR33821.1 & 0.49 & 0.00 & Glutathione peroxidase $4 \mathrm{a}$ & Cyprinus carpio & $4.00 E-116$ \\
\hline ABF57552.1 & 0.25 & 0.00 & Pi-class glutathione-S-transferase & Cyprinus carpio & $4.00 E-149$ \\
\hline ACN11531.1 & 0.49 & 0.01 & Cytochrome oxidase subunit II & Cyprinus carpio & $5.00 E-123$ \\
\hline BAB88920.1 & 0.43 & 0.00 & Complement control protein factor I-A & Cyprinus carpio & 0 \\
\hline ACA64701.1 & 0.31 & 0.00 & Liver-basic fatty acid-binding protein $b$ & Cyprinus carpio & $7.00 E-84$ \\
\hline BAA36700.1 & 0.16 & 0.00 & Serum amyloid A protein & Cyprinus carpio & $2.00 E-46$ \\
\hline CAC34942.1 & 0.27 & 0.00 & Apolipoprotein A-I & Cyprinus carpio & $9.00 E-114$ \\
\hline CAC12738.1 & 0.42 & 0.01 & Retinol-binding protein & Cyprinus carpio & $4.00 E-160$ \\
\hline BAA36618.1 & 0.45 & 0.00 & Complement C3-H1 & Cyprinus carpio & 0 \\
\hline AEM37715.1 & 0.28 & 0.01 & Plasminogen & Epinephelus bruneus & $4.00 E-16$ \\
\hline ACD99642.1 & 0.27 & 0.01 & Transferrin variant $\mathrm{G}$ & Cyprinus carpio & $1.00 E-151$ \\
\hline
\end{tabular}

club cells, as well as vacuolation of the epithelium. Mucous and club cells located in the epidermal layer of the skin are responsible for the excretion of waste, respiration, ionic and osmotic regulation, disease resistance, communication, and other protection functions [34]. An increase in the number and size of these cells may be a necessary response of the body to counteract the effects of exogenous chemicals, such as nanoparticles. However, if nanoparticle concentrations exceed the resistance level of the skin and excretory systems, they may have a lethal effect on cells. For example, when the fish were exposed to $200 \mu \mathrm{g} / \mathrm{L}$ of Ag-NPs (as shown in Figure 5(d)), vacuolation of the epidermal epithelium was observed. Malfunctioning or injured skin may also cause nanoparticles to have a fatal effect on the fish. Therefore, in 
this study, stresses caused by the exposure of common carp to Ag-NPs may have potentially toxic effects.

In this study, fish exposed to Ag-NPs were not subjected to any lethal effects. However, chronic exposure to AgNPs may cause other types of damage that kill fish. One impact of Ag-NPs is the inhibition of the oxygen/carbon dioxide exchange process because of injury to the respiratory organ (gills). As shown in Figure 6, the exposure of fish to Ag-NPs initially caused the bifurcation of the filament (Figure 6(b)), an increase in the number and size of mucous cells (Figure 6(c)), and hyperplasia of the lamellar epithelium (Figure 6(d)). Similar to the effects on the skin, these slight changes to the gills did have a severe effect on the fish, but it could result in potentially fatal effects if the carp were exposed to higher concentrations of Ag-NPs over an extended period. The adverse effects observed in the liver of the exposed carp (Figure 7), such as atrophy of the hepatocyte nucleus and eosinophilic granule formation, may therefore be used as indicators.

We used genomic analysis to evaluate changes in gene expression towards Ag-NP exposure in the liver of common carp, and we subsequently selected several biomarkers of Ag-NP toxicity. In our microarray data, the MAX gene was upregulated in response to Ag-NP treatment. MAX is a transcription factor that belongs to the myc protein family [35]. Repression of MAX has a lethal effect on the early embryonic blastocyst [36]. However, the upregulation of MAX blocks apoptosis in endothelial cells [37] and is involved in the maintenance of healthy morphology in the retinal ganglion cells of rats [38], indicating the presence of protective cellular functions. In addition, this observation might indicate that programmed cell death and cell morphology are mediated and orientated by MAX, leading to cellular defense against Ag-NP toxicity.

In our microarray data, the $R B P$ gene was downregulated on Ag-NP exposure. Generally, RBP has been reported to solubilize transport proteins and protect their ligands. This protein regulates the disposition, metabolism, and activity of retinoids [27]. Repression of RBP in the epidermis might cause a reduction in the amount of retinol in keratinocytes, indicating cornification of the epidermis [39]. Another study documented that the underexpression of RBP is associated with inhibiting differentiation and the formation of large tumors in hepatocellular carcinoma [40]. These observations might indicate that Ag-NPs cause abnormal retinoid metabolism, resulting in tumorigenesis.

In our microarray data, GST was downregulated after $96 \mathrm{~h} \mathrm{Ag-NP}$ treatment. GST has been reported to play a critical role in the detoxification of various types of toxicants (such as carcinogens) and has a protective effect on ROSmediated DNA damage [41-45]. A recent assessment indicated that GST activity might be useful towards evaluating oxidative stress [46, 47]. Hence, Ag-NPs might induce the accumulation of intracellular oxidative stress, giving rise to abnormal biological functions of responsive components, including GST. Gene expression level of GST obtained from microarray analysis was found to be downregulated while the GST activity was induced in presence of Ag-NPs, particularly after $96 \mathrm{~h}$ exposure to $100 \mu \mathrm{g} / \mathrm{L}$ in common carp liver tissue.
Possible explanation is that the inhibitory gene expression at mRNA level manifests at initial stage due to the Ag-NPs toxic effect whereas the induction of GST activity would play an important role as defensive mechanism in response to the Ag-NPs-induced oxidative stress at later stage.

At present, while the functions of many common carp genes remain under investigation, the inferred functions of unknown genes might be used as putative bioindicators of Ag-NP toxicity. The results of the current study indicated that MAX, GST, and RBP might be viable candidates as Ag-NP biomarkers. However, detailed study of the toxicitymediated molecular mechanisms of Ag-NPs and further functional analysis of common carp genes are necessary to elucidate cellular responses to Ag-NPs and the detoxification processes.

\section{Conclusion}

Citrate-capped Ag nanoparticles dispersed well in freshwater, with an estimated average particle size of 7-21 nm (TEM) and 72-91 nm (DLS analysis). Despite the formation of aggregations/agglomerations in the solution, nanosized particles of citrate-Ag-NPs were dominant. Among the examined tissues, liver was the most susceptible to changes in particle concentration. The antioxidant enzyme system was mostly active in the liver. According to the analysis of the antioxidant enzyme system and other biochemical parameters, liver was the most severely affected organ when the carp were exposed to Ag-NPs. The activities of antioxidant enzymes, such as GST and CAT, fluctuated with different Ag-NP concentrations, whereas SOD activity remained stable. The histopathology showed the following: (1) in the skin: an increase in the number and size of club cells and mucous cells and vacuolation of the epithelium; (2) in the gill: bifurcation of the filament, an increase in the number of mucous cells, and hyperplasia of the lamellar epithelium; (3) in the liver: atrophy of the hepatocyte nucleus and accumulation of eosinophilic granules. The adverse effects recorded in the current study were not severe enough to cause carp mortality, but they might potentially lead to lethal effects if the fish were exposed to higher concentrations of Ag-NPs over a longer period.

\section{Acknowledgments}

The authors would like to thank Seok-Won Jeong, Kyung Hee University, for assistance with microarray analysis and paper preparation.

\section{References}

[1] T. Masciangioli and W.-X. Zhang, "Environmental technologies at the nanoscale," Environmental Science and Technology, vol. 37, no. 5, pp. 102A-108A, 2003.

[2] G. J. Nohynek, J. Lademann, C. Ribaud, and M. S. Roberts, "Grey Goo on the skin? Nanotechnology, cosmetic and sunscreen safety," Critical Reviews in Toxicology, vol. 37, no. 3, pp. 251-277, 2007.

[3] G. Oberdörster, A. Maynard, K. Donaldson et al., "Principles for characterizing the potential human health effects from 
exposure to nanomaterials: elements of a screening strategy," Particle and Fibre Toxicology, vol. 2, article 8, 2005.

[4] C. N. Duong, D. Schlenk, N. I. Chang, and S. D. Kim, "The effect of particle size on the bioavailability of estrogenic chemicals from sediments," Chemosphere, vol. 76, no. 3, pp. 395401, 2009.

[5] L. HAO, Z. WANG, and B. XING, "Effect of sub-acute exposure to $\mathrm{TiO}_{2}$ nanoparticles on oxidative stress and histopathological changes in Juvenile Carp (Cyprinus carpio)," Journal of Environmental Sciences, vol. 21, no. 10, pp. 1459-1466, 2009.

[6] G. Oberdörster, E. Oberdörster, and J. Oberdörster, "Nanotoxicology: an emerging discipline evolving from studies of ultrafine particles," Environmental Health Perspectives, vol. 113, no. 7, pp. 823-839, 2005.

[7] M. N. Moore, "Do nanoparticles present ecotoxicological risks for the health of the aquatic environment?" Environment International, vol. 32, no. 8, pp. 967-976, 2006.

[8] A. Nel, T. Xia, L. Mädler, and N. Li, "Toxic potential of materials at the nanolevel," Science, vol. 311, no. 5761, pp. 622-627, 2006.

[9] B. Nowack and T. D. Bucheli, "Occurrence, behavior and effects of nanoparticles in the environment," Environmental Pollution, vol. 150, no. 1, pp. 5-22, 2007.

[10] EPA, U. S. Integrated Risk Information System (IRIS), http:// www.epa.gov/IRIS/subst/0099.htm.

[11] S. M. Hussain, K. L. Hess, J. M. Gearhart, K. T. Geiss, and J. J. Schlager, "In vitro toxicity of nanoparticles in BRL 3A rat liver cells,” Toxicology in Vitro, vol. 19, no. 7, pp. 975-983, 2005.

[12] L. Braydich-Stolle, S. Hussain, J. J. Schlager, and M. C. Hofmann, "In vitro cytotoxicity of nanoparticles in mammalian germline stem cells," Toxicological Sciences, vol. 88, no. 2, pp. 412-419, 2005.

[13] H. C. Wen, Y. N. Lin, S. R. Jian et al., "Observation of growth of human fibroblasts on silver nanoparticles," Journal of Physics, vol. 61, no. 1, pp. 445-449, 2007.

[14] K. Kawata, M. Osawa, and S. Okabe, "In vitro toxicity of silver nanoparticles at noncytotoxic doses to HepG2 human hepatoma cells," Environmental Science and Technology, vol. 43, no. 15, pp. 6046-6051, 2009.

[15] S. Kim, J. E. Choi, J. Choi et al., "Oxidative stress-dependent toxicity of silver nanoparticles in human hepatoma cells," Toxicology in Vitro, vol. 23, no. 6, pp. 1076-1084, 2009.

[16] J. P. Wise, B. C. Goodale, S. S. Wise et al., "Silver nanospheres are cytotoxic and genotoxic to fish cells," Aquatic Toxicology, vol. 97, no. 1, pp. 34-41, 2010.

[17] Y. Wu, Q. Zhou, H. Li, W. Liu, T. Wang, and G. Jiang, "Effects of silver nanoparticles on the development and histopathology biomarkers of Japanese medaka (Oryzias latipes) using the partial-life test," Aquatic Toxicology, vol. 100, no. 2, pp. 160$167,2010$.

[18] B. Lee, K. Kim, S. Jeong et al., "Gene expression profiling of silver nanoparticles-exprosed Cyprinus carpio using DNA microarray," Cancer Prevention Research, vol. 16, no. 2, pp. 147-154, 2011.

[19] OECD Test No. 203: fish, Acute toxicity test; Organisation for Economic Co-operation and Development: Paris, France, 1992.

[20] H. Abei, "Catalase," in Methods of Enzymatic Analysis, H. U. Bergmeyer, Ed., pp. 673-684, Academic Press, New York, NY, USA, 1974.

[21] M. M. Bradford, "A rapid and sensitive method for the quantitation of microgram quantities of protein utilizing the principle of protein dye binding," Analytical Biochemistry, vol. 72, no. 1-2, pp. 248-254, 1976.
[22] S. F. Altschul, W. Gish, W. Miller, E. W. Myers, and D. J. Lipman, "Basic local alignment search tool," Journal of Molecular Biology, vol. 215, no. 3, pp. 403-410, 1990.

[23] E. J. Park, J. Yi, K. H. Chung, D. Y. Ryu, J. Choi, and K. Park, "Oxidative stress and apoptosis induced by titanium dioxide nanoparticles in cultured BEAS-2B cells," Toxicology Letters, vol. 180, no. 3, pp. 222-229, 2008.

[24] E. J. Park, J. Yoon, K. Choi, J. Yi, and K. Park, "Induction of chronic inflammation in mice treated with titanium dioxide nanoparticles by intratracheal instillation," Toxicology, vol. 260, no. 1-3, pp. 37-46, 2009.

[25] G. G. Skouteris and C. H. Schröder, "c-myc and max interactions in quiescent and mitogen-stimulated primary hepatocytes," Experimental Cell Research, vol. 225, no. 2, pp. 237-244, 1996.

[26] B. Ketterer and D. J. Meyer, "Glutathione transferases: a possible role in the detoxication and repair of DNA and lipid hydroperoxides," Mutation Research, vol. 214, no. 1, pp. 33-40, 1989.

[27] N. Noy, "Retinoid-binding proteins: mediators of retinoid action," Biochemical Journal, vol. 348, no. 3, pp. 481-495, 2000.

[28] V. L. Colvin, "The potential environmental impact of engineered nanomaterials," Nature Biotechnology, vol. 21, no. 10, pp. 1166-1170, 2003.

[29] D. B. Warheit, "How meaningful are the results of nanotoxicity studies in the absence of adequate material characterization?" Toxicological Sciences, vol. 101, no. 2, pp. 183-185, 2008.

[30] K. T. Douglas, "Mechanism of action of glutathione-dependent enzymes.", Advances in enzymology and related areas of molecular biology, vol. 59, pp. 103-167, 1987.

[31] G. Federici, B. J. Shaw, and R. D. Handy, "Toxicity of titanium dioxide nanoparticles to rainbow trout (Oncorhynchus mykiss): gill injury, oxidative stress, and other physiological effects," Aquatic Toxicology, vol. 84, no. 4, pp. 415-430, 2007.

[32] P. Chelikani, I. Fita, and P. C. Loewen, "Diversity of structures and properties among catalases," Cellular and Molecular Life Sciences, vol. 61, no. 2, pp. 192-208, 2004.

[33] R. Van der Oost, J. Beyer, and N. P. E. Vermeulen, "Fish bioaccumulation and biomarkers in environmental risk assessment: a review," Environmental Toxicology and Pharmacology, vol. 13, no. 2, pp. 57-149, 2003.

[34] K. L. Shephard, "Functions for fish mucus," Reviews in Fish Biology and Fisheries, vol. 4, no. 4, pp. 401-429, 1994.

[35] E. M. Blackwood and R. N. Eisenman, "Max: a helix-loophelix zipper protein that forms a sequence-specific DNAbinding complex with Myc," Science, vol. 251, no. 4998, pp. 1211-1217, 1991.

[36] H. Shen-Li, R. C. O’Hagan, H. Hou, J. W. Horner, H. W. Lee, and R. A. DePinho, "Essential role for Max in early embryonic growth and development," Genes and Development, vol. 14, no. 1, pp. 17-22, 2000.

[37] M. Shichiri, H. Kato, M. Doi, F. Marumo, and Y. Hirata, "Induction of Max by adrenomedullin and calcitonin generelated peptide antagonizes endothelial apoptosis," Molecular Endocrinology, vol. 13, no. 8, pp. 1353-1363, 1999.

[38] H. Petrs-Silva, V. Chiodo, L. B. Chiarini, W. W. Hauswirth, and R. Linden, "Modulation of the expression of the transcription factor Max in rat retinal ganglion cells by a recombinant adeno-associated viral vector," Brazilian Journal of Medical and Biological Research, vol. 38, no. 3, pp. 375-379, 2005.

[39] G. Siegenthaler and J. H. Saurat, "Loss of retinol-binding properties for plasma retinol-binding protein in normal human epidermis," Journal of Investigative Dermatology, vol. 88, no. 4, pp. 403-408, 1987. 
[40] J. C. Y. Ho, S. T. Cheung, W. S. Poon, Y. T. Lee, I. O. L. Ng, and S. T. Fan, "Down-regulation of retinol binding protein 5 is associated with aggressive tumor features in hepatocellular carcinoma," Journal of Cancer Research and Clinical Oncology, vol. 133, no. 12, pp. 929-936, 2007.

[41] A. E. Salinas and M. G. Wong, "Glutathione S-transferases-a review," Current Medicinal Chemistry, vol. 6, no. 4, pp. 279309, 1999.

[42] R. Whalen and T. D. Boyer, "Human glutathione S-transferases," Seminars in Liver Disease, vol. 18, no. 4, pp. 345-358, 1998.

[43] M. C. J. Wilce and M. W. Parker, "Structure and function of glutathione S-transferasese," Biochimica et Biophysica Acta, vol. 1205, no. 1, pp. 1-18, 1994.

[44] J. D. Hayes and D. J. Pulford, "The glutathione S-transferase supergene family: regulation of GST and the contribution of the isoenzymes to cancer chemoprotection and drug resistance," Critical Reviews in Biochemistry and Molecular Biology, vol. 30, no. 6, pp. 445-600, 1995.

[45] J. D. Hayes and R. C. Strange, "Potential contribution of the glutathione S-transferase supergene family to resistance to oxidative stress," Free Radical Research, vol. 22, no. 3, pp. 193207, 1995.

[46] V. M. E. Neefjes, C. T. A. Evelo, L. G. M. Baars, and C. E. Blanco, "Erythrocyte glutathione $\mathrm{S}$ transferase as a marker of oxidative stress at birth," Archives of Disease in Childhood, vol. 81, no. 2, pp. F130-F133, 1999.

[47] M.-K. Yeo and H.-E. Kim, "Gene expression in zebrafish embryos following exposure to $\mathrm{Cu}$-doped $\mathrm{TiO}_{2}$ and pure $\mathrm{TiO}_{2}$ nanometer-sized photocatalysts," Molecular and Cellular Toxicology, vol. 8, pp. 127-137, 2012. 

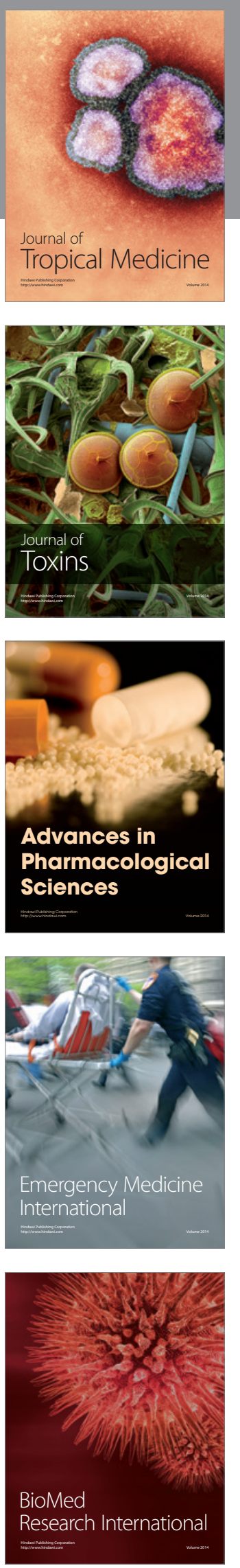
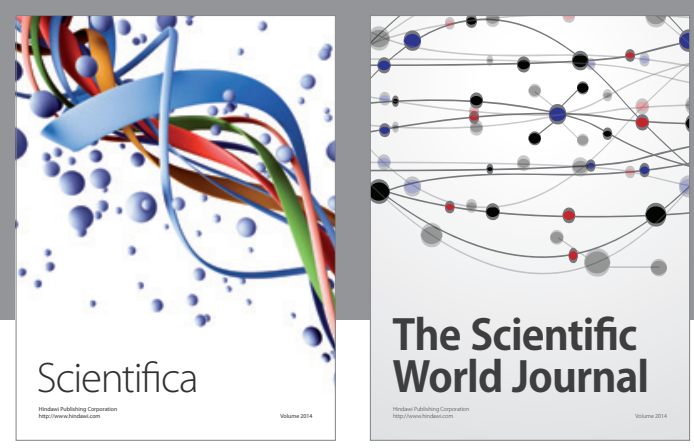

The Scientific World Journal
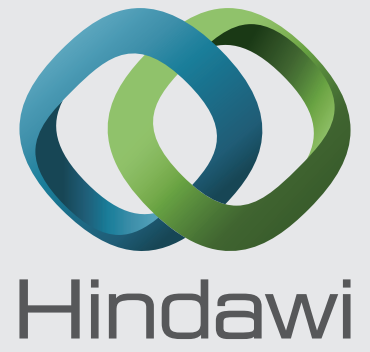

Submit your manuscripts at

http://www.hindawi.com
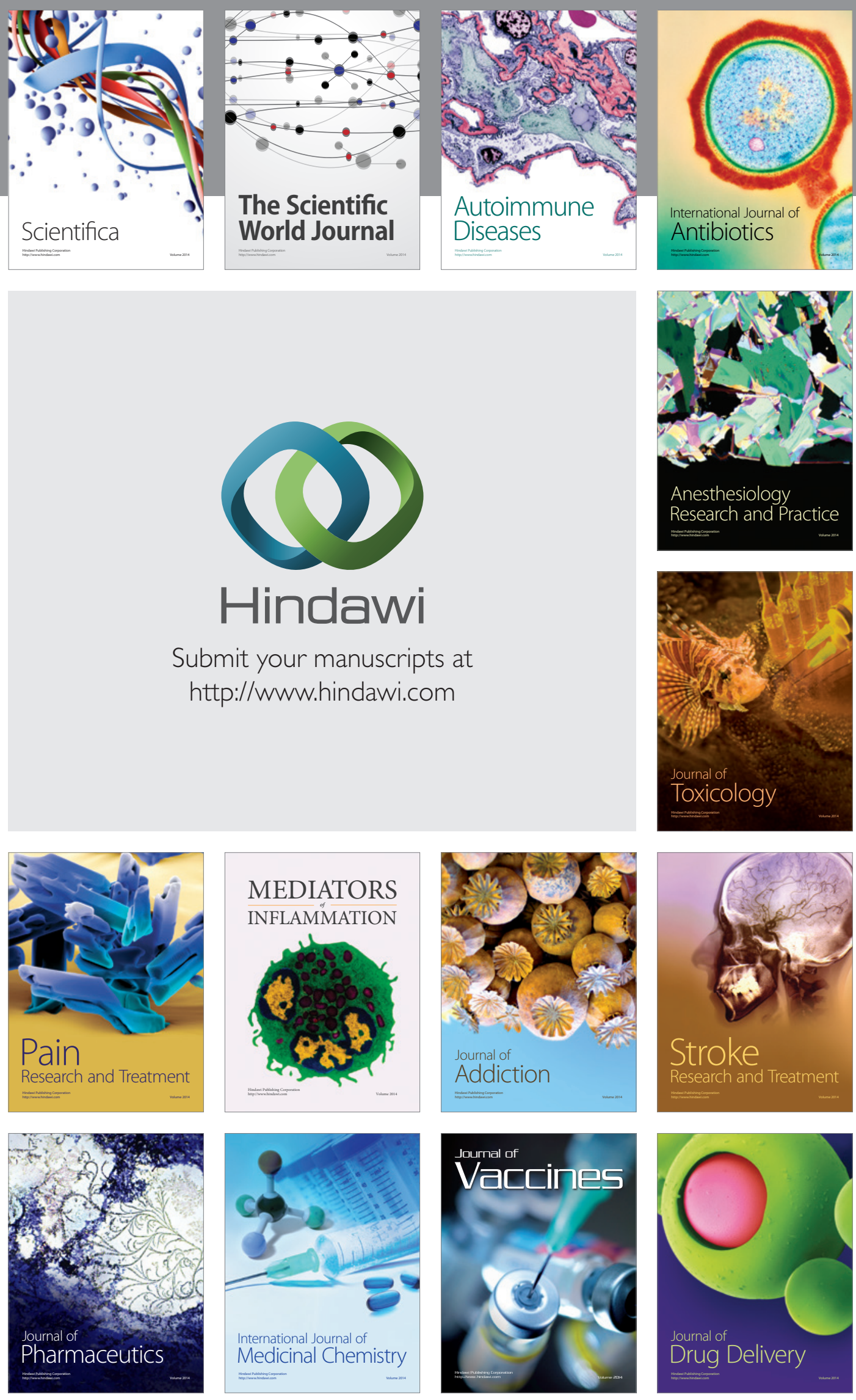